\title{
Systems competing for mobile factors: decision making based on hard vs. soft locational factors
}

\author{
Roxana CLODNIȚCHI \\ Bucharest University of Economic Studies, Bucharest, Romania \\ roxana.clodnitchi@fabiz.ase.ro
}

\begin{abstract}
The paper explores the links between capital relocation and soft locational factors addressing the quality of the business environment and the quality of life within the European Union. System competition is viewed as a competition between countries for the mobile factors capital and labour. The issue of systems competition is topical and insufficiently explored by contemporary literature. The scarcity of scientific papers describing the links between system competition theories and contemporary corporate geography theories, especially of the ones including the analysis of soft location factors, is a challenging aspect, which motivates the choice of this subject. This paper's primary aim is to deliver an overview of the basic corporate geography conceptions, stressing the importance of soft location factors in today's competition between systems for the mobile factors capital and labour. The paper further contains an analysis of the correlations between indicators regarding the institutional design of countries as developed by the World Bank (Ease of Doing Business), the Happiness Scale and the latest available data of FDI Stocks for the EU countries (2016). The relevance of such a study is based on the evidence that the contemporary business education relies on an extensive knowledge of the business environment. In the circumstance of similar infrastructural conditions, the main difference between locations is made by soft location factors. Since developed economies are characterised by a high degree of ubiquity of soft factors, the paper concludes that developing and emerging economies should foster the development of their soft location factors.
\end{abstract}

Keywords: soft location factors, systems competition, locational decisions, correlations, FDI Stocks, happiness, Doing Business.

Please cite the article as follows: Clodnițchi, R. (2017), "Systems competing for mobile factors: decision making based on hard vs. soft locational factors", Management \& Marketing. Challenges for the Knowledge Society, Vol. 12, No. 4, pp. 633-651. DOI: 10.1515/mmcks-20170037.

\section{Introduction}

Indeed, it is not only companies, brands, products and services that compete with one another, but also cities, regions and, of course, countries. These systems compete for the (meanwhile) mobile factors, namely capital and labour by using a wide range of instruments to be described further within this article. System competition in its "classical" meaning refers to competition between communism and capitalism. These competitor systems fought for economic, cultural and, most importantly, military dominance. This competition took the form of mutual observation, imitation and innovation within closed borders. Systems competition today aims less at military dominance. This focus was replaced by a new element that fundamentally changed the competition's nature: the international migration of capital and labour as a reaction to national policy decisions. Peter Auer underlines that, while the liberal 19th century form of globalisation produced extraordinary wealth, it came at the cost of intolerable 
poverty, and ultimately ended in World War I, the world recession of 1929 and World War II (Auer, 2006).

Due to the ongoing liberalisation process promoted by the World Trade Organisation and by international organisations like the European Union and to the lower relative transportation costs, relocation becomes much easier. Thus, corporate geography underlies a deep process of change. The migration response of production factors makes states and regions behave like firms which compete for customers by offering them attractive combinations of tax, prices and public goods.

Understanding the new systems competition is of utmost importance for the European countries since the rules under which they interact among themselves and with third countries are changing rapidly. A few decades ago the borders of the European countries were closed for migrants, customs duties had to be paid on crossborder transactions and most countries even had capital controls (Sinn, 2003). Today we are enjoying the 'four basic freedoms' that were proclaimed in the 1957 Treaty of Rome - the freedom of movement of goods, people, services and capital over borders within the EU - as well as lowering barriers of movement outside the EU.

An obvious aspect of globalisation is the migration of people from developing or emerging economies to more developed ones. The time when lack of knowledge and transport costs hindered such migration is long since passed. Global television coverage, the wide spread access to the world wide web as well as tourism are spreading the news about the prosperity of the Western industrial countries even to the most distant Himalayan villages, and dropping transportation costs makes relocation accessible to many. This paper does not take forced migration into account.

On the other hand, while as well as the digitalisation and the relocation of production activities, both associated with the loss of manufacturing jobs, are not new phenomena, the increased global competition in the high-skilled job sector has become a major concern in the developed countries. The rapid development of the internet, the improvement of road and flight infrastructure and the cost decrease for communication and transportation have all contributed to the increase of offshore outsourcing. As a result, service-based companies are now hiring workers abroad to fulfil tasks previously carried out in-house in order to save costs. This process is even more intense since companies not only outsource standardised tasks and back office functions without direct customer contact, but also highly specialised professions which can be telemediated.

Potential job losses represent just one of the many aspects of system competition. Hans W. Sinn provides a thorough pessimistic economic analysis of the competitive forces at work between nations and governments in his book "The New System Competition". He carefully analyses state activities referring to taxation, public goods provision, income redistribution, environmental policy, safety standards, and competition policy (Sinn, 2003). However, he fails to take a closer look to location factors considered by others at least as important as the ones mentioned above.

For the mobile factors it is, according to the classical business location theory, first and foremost the "hard facts" that count, whereas the so-called soft location factors are, if taken into account, merely the "icing on the cake". Nevertheless, today's existing infrastructure and the reduced transportation costs make "closeness", which lies at the bottom of the classic theory, seem relative. When examining the factors that 
encourage competitiveness and innovation, these turn out to be not only of hard, but also of soft nature, like the quality of the business environment and the quality of life.

Further, authors like Miron et al. (2009) have shown in the past that the dominant trend will not be on the neoclassic relocation of capital to poor regions, looking for cheap inputs, but rather the further concentration around the most advanced places and wealthy regions, having as a consequence further deepening of the gaps vis-à-vis the neglected regions. The question arising from this conception is is it the wealth itself that attracts capital or rather other preconditions - maybe of soft nature - associated with wealth.

This paper aims firstly at describing the main theoretical approaches of the location theory. Secondly, there will be a presentation of the location factors influencing the decision makers in their choice of placing a new unit of production, sales or control. In addition, it will also include various methods of classifying location factors, emphasising "hard" and "soft" location factors. Subsequently, the evaluation of location factors and the decision-taking process on the matter (at individual \& aggregate level) will be discussed. Last but not least, the problem of comparative and competitive advantage of different countries or regions will be dealt with, stressing the existing correlations between the migration of capital and soft locational factors of the target countries.

\section{Corporate geography and location factors}

According to Laulajainen and Stanford (1995) "corporate geography examines the spatial structures and behaviour of business corporations [...] (or) discusses where and why firms locate units of production, sales and control (plants, stores and offices), and how these interact with each other, suppliers and customers".

Corporations (companies, firms, undertakings, enterprises), households and public agencies are the operational units of an economy. Each undertaking has at least one location or several, depending on domain, size and structure. It also has connections to suppliers, customers and other legal units within the same geographical space. The way undertakings organise their space is of great importance for their own well-being and for the health of the national and local economies in which they operate. This importance becomes obvious in market economies, where undertakings bear the responsibility for a substantial share of investment decisions and the bulk of operational decisions.

\section{Locational decision making}

Healey and Ilbery (1992) published an exhaustive study on the development of schools of thought on corporate geography. They argue that traditional studies on economic geography were rather of ideographic, deterministic nature. They were stressing the unique by collecting digests of factual information about economic production and trade between different parts of the world. Besides that, they were assuming that the differences in the availability of physical factors are determining the distribution of economic activity throughout the world. Emphasising the particularities of different areas or regions by comparing them was a widespread practice. The next step was the movement away from simple description of location patterns and towards the identification of the process creating such patterns. 
The ideographic studies and their determinism became subject of criticism especially during the 1950s. It was argued that:

- they encouraged the increasing fragmentation of economic geography (researchers became specialised in particular regions / on particular products),

- they were too concerned with the way economic phenomena is spatially arranged and generally ignoring the reasons for these arrangements.

Since the 1950s, the studies of economic location have been dominated by three major perspectives: neoclassical, behavioural and structuralist approaches.

The Neoclassicists were the first ones to make real attempts to develop generalisations and principles in economic geography. The search for regularities in patterns of economic activity became their main focus of interest. They were assuming that:

- there is an identifiable order to the material world,

- economic activity takes place within a freely competitive manner and on a uniform land surface,

- man acts like "homo economicus".

The derived patterns of the neoclassical theory were rather the result of deductive reasoning (reasoning from general principles) than observation, which led to normative geographical models. These models concentrated upon the interrelationship of a few factors and their spatial consequences.

The partial equilibrium models produced the optimal location and/or land-use pattern, where profits were maximised and/or costs were minimised. Distance was playing the key-factor in this approach. It was assumed to be a predominant influence in human behaviour and special patterns could be accounted for by examining the relationship between distance and transportation costs. Other location factors described in the next section of this paper were assumed not to have sufficient significance to be incorporated into the decision models. This approach however proved later to be incomplete or even faulty. Besides the fact that it was based on utopic assumptions (e.g. the rational acting "homo economicus"), the models ignored a wide range of non-economic reasons. The changes in the economical world determined scientists to realise that the neoclassical models were rather poor descriptions of the reality. Attention began to be directed more towards inductive reasoning and the micro-scale.

Behaviourists considered the individual to be the main motive force in economic affairs. Therefore, the behaviour of individuals was inductively investigated in order to discover generalisations. Generalisation was sought, similar to the neoclassical approach, only by different means. It is assumed that the neoclassic approaches tightened the links between geographers and economists while the behavioural approaches of economic geography strengthened the connections between geographers, sociologists and psychologists. Emphasis was put on a wider range of variables that help shaping patterns of economic activity, including motives, values, preferences, perceptions and opinions. Behaviouralism stressed the nonoptimal behaviour of entrepreneurs and attempted to produce alternative theories to those based on the "homo economicus". Behaviouralists assumed that: 
- decision-makers do not have perfect information when making location choices,

- decision-makers do not have the ability to use the whole amount of information to their disposal,

- conscious decisions are often made knowing that they are not optimal and that profits will not be maximised,

- business may attempt to satisfy multiple goals besides profits, like: security, growth, risk minimisation, self-preservation, satisfaction, ...

Behavioural studies of economic location have mainly focused on the analysis of long term decision-making, as this has a major impact on the economic landscape. Most of their work was of empirical nature, seeking to "measure" perceptions, attitudes, and behaviour and to derive generalisations from the case studies.

The behavioural approach was criticised in specialised literature, the main points of critique being:

- failing to solve the neoclassical problem of poor explanation, explaining rather how location decisions are taken than the reasoning that lay behind them,

- placing too much emphasis on the attitudes of individual entrepreneurs and too little on behaviour itself,

- approaches under "behavioural" umbrella vary considerably,

- too much emphasis on "choice",

- separating the individual from the broader environment, too much autonomy is afforded to factors at the "firm" level.

Still, the idea that variables like motives, values, preferences, perceptions and opinions help shaping patterns of economic activity was not dismissed. In today's economy based on knowledge and information, these two factors adding the factor choice gain more importance than they did in the past century, and can play an important role in system competition.

Behaviouralism was followed by Structuralism. According to the structuralist perspective, space becomes what an economy makes out of it. The economic landscape is the product of the overall structure of the economic system in which economic decision-makers operate.

A main difference to the behavioural approach is the holistic perspective that structuralists adopt. They argue that behaviour is constrained by wider social, political and economic processes. The economic geographers who adopted a structuralist perspective relate the changing geography of economic activity to the structure of society and to economic and social relations. They are particularly interested in the macro-socio-economic processes which underlie spatial patterns of economic activity.

The structuralist approach places emphasis on the analysis of production itself, on the role of labour, and of the nature of the labour process as key element in the production process, rather than on location factors (Boddy, 1987).

Structuralists assume that:

- the crucial factor in the development of any spatial structure is the way in which surplus capital is circulated, concentrated and utilised in space (Johnson, 1987) 
- (with the increased mobility of capital) uneven spatial development, also a precondition for system competition, is a necessary precondition for the process of capital accumulation and for the spatial division of labour (Massey, 1984),

- explanations of economic patterns cannot be found within the patterns themselves

- there is a historical sequence; the superstructures are founded on prevailing modes of production, which build up internal contradictions over time and are replaced by other modes, consequently, location and land-use decisions are specific to a certain time period, changes in the location of industry are a function between two main groups of factors (Massey, 1981): changes in economic conditions (which affect the requirements of production) and the changing geographical environment.

According to Walmsley and Leevis (Walmsley \& Leevis, 1984), the main points of critique to the structuralist approach are:

- the macro-economic perception is overemphasised, using "fragments of reality to illustrate the theory rather than using theory to provide insights into the real world"

- the importance of variations in economic behaviour at the level of individual undertaking is ignored by assuming that individual behaviour is determined by larger structures.

In order to be able to understand system competition, it is necessary to adopt a moderate (behaviouristic-structuralist) point of view, stressing the individualistic behaviour and decision-making process at firm level, influenced by larger structures, like the actions of states, as macroeconomic actors in world economy. The behaviour of mobile economic entities (capital, labour) depends on location factors.

In order to understand the location decision-making process, we have to clearly delimitate the term "location decision" (Gabrow et al., 1995). Direct location decisions are:

- shutdown or displacement of the (whole or parts of the) undertaking

- upgrades at the expenses of other locations

- shrinkage or omission of an upgrade on behalf of others

- opening subsidiaries or launching a new company.

The indirect location decisions are containing all economic alternatives to the above listed measures. The outsourcing of a production point as an alternative to upgrading it or opening a new production-site is a good example for an indirect location decision.

The decision not to go elsewhere, or rather to invest instead of choosing closure are also location decision (Laulajainen and Stanford, 1995).

Locational decision making is difficult and risky. There is no single place which is best for all location factors. It is necessary to weigh and aggregate the many location influences. There are several analysis techniques, some of which simple and some sophisticated, which are used with varying degree of success (Laulajainen and Stanford, 1995). There is no solution to match all needs; every location decision has its own particularities depending on the goals of the undertaker. Every analysis of the importance of particular location factors asks for a different approach (Gabrow, 2005) 
depending on the type of location decision, the branch, the functional type of undertaking (production, sales or control), the dimension of the enterprise, the dimension of settlement and type of settlement. Simultaneously, all the spatial decisions are conditioned by the dynamics of the outside world in which the enterprise must produce, sell and compete (Laulajainen and Stanford, 1995). The sum of the location decisions of a company produces its corporate geography. The location decision for each unit is based on some combination of location factors. Location decisions are made every day by assuming that the best available data and forecasts are adequate. At some point in its existence, each company faces the choice of new investment or closure. A location investment has a useful life varying between 10 and 50 years.

\section{Location factors}

Every locational choice is influenced by several factors, which become criteria for the undertakings when they choose a site (Bienert, 1996). The criteria which are considered by the undertakings in their location choice are characterised by a continuous process of change, caused by the alteration of the economic and social framework. Still, not all location factors are equally affected by this process, fact that determined the theoreticians to classify them.

There are several ways to do this, some of them being described in the next paragraphs. Firstly, when we describe a location, there are two major aspects which have to be considered: situation and site (Laulajainen and Stanford, 1995). A land area's situation is its location relative to other important spatial dimensions. Site factors are the absolute measures of the relevant physical characteristics of a specific parcel of land.

Some factors can be described both relatively and in absolute measures (quantitative ones), while others just by comparison to others or by "image" (qualitative ones) (Hansmann, 1974). The next graphic shows a classification of location factors on the basis of qualitative-quantitative criteria. 


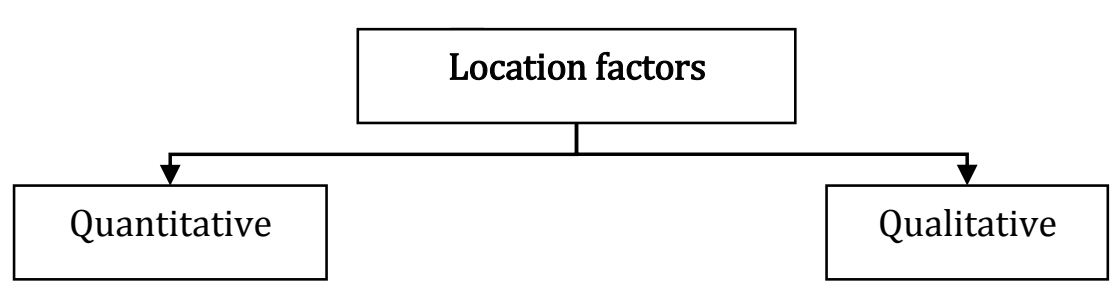

- Transportation costs

- Costs of land

- Building related costs

- Labour related costs

- Cost of materials

- Spatial related financing costs

- Subsidies

- Taxes

- Spatial related distribution costs

Figure 1. Classification of location factors after Hansmann

- Attributions of land

- Situation of land

- Labour market

- Transportation sector

- Infrastructure

- Goodwill of the branch

Source: Kinkel, 2004, p. 51.

Still when looking at this classification, many quantitative location aspects are quite difficult to measure. The labour related cost, for example, does not include the costs for having less motivated or less creative employees than in a different location.

The classical classifications, on the other hand, consider mainly the costs of production and distribution. Behrens for example, distinguished between supplyoriented and demand-oriented location factors, as shown in the figure below (Behrens, 1971). He stressed the importance of supply-oriented factors. 


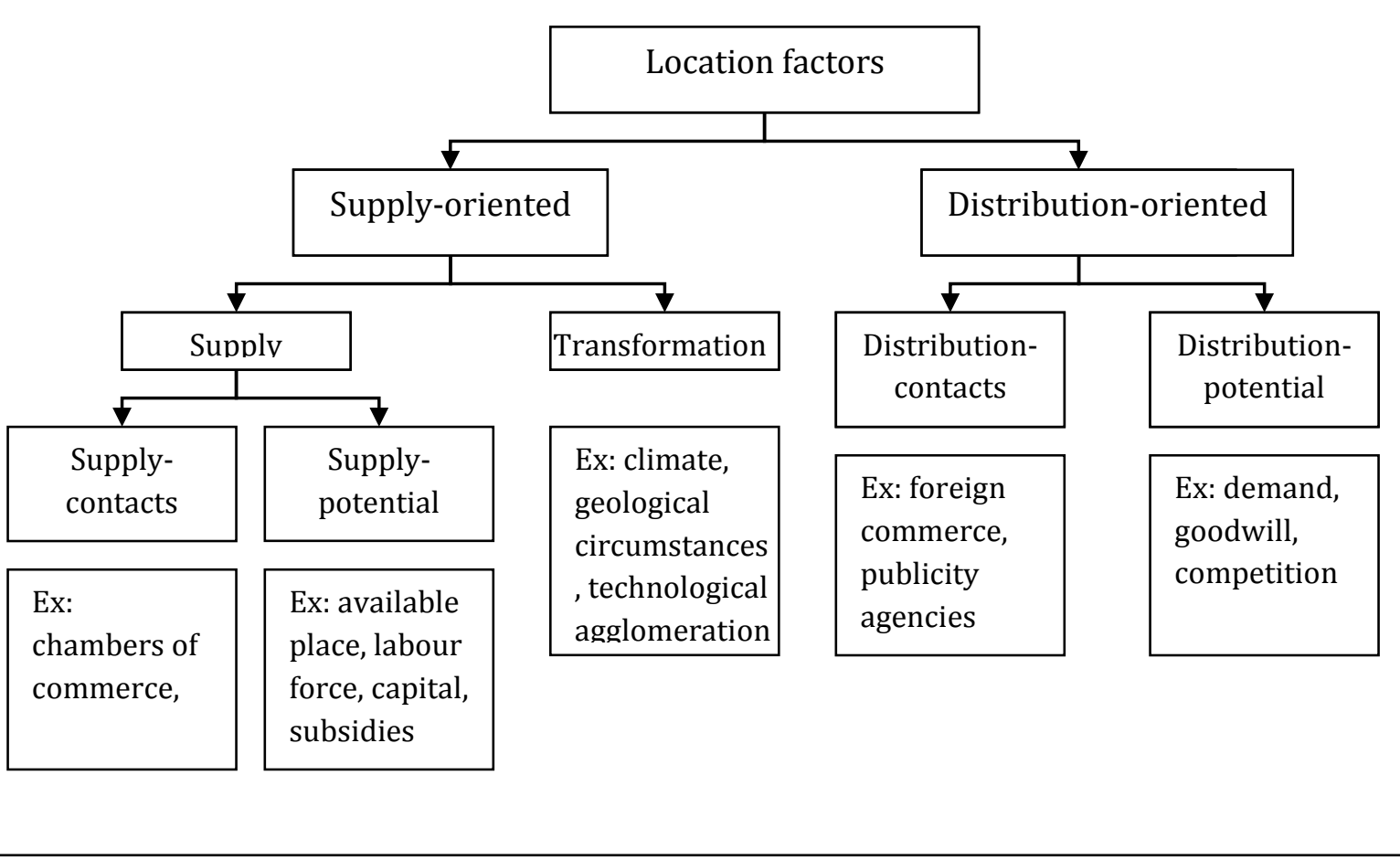

Figure 2. Classification of location factors after Behrens

Source: Kinkel, 2004, p. 51.

The transformation of the market (from a seller-market to a buyer-market) lead the demand-oriented location factors to gain more and more importance. The number of disrupters from the theoretical framework by actual cases caused the contemporary approaches of the topic to a change of view. Nowadays, the parameters which flow into the location decision making process are more and more diverse from case to case, which leads to formally ignored factors like customer or competition behaviour, image of the location or change in the structure of the location to be taken into account. This lead to the new way of classifying location factors by distinguishing between cost-oriented, general factors and special, social and psychological determined ones (BAG, 1979). 1991 Reichhard classifies the location factors in "hard" and "soft" ones (Reichhard, 1991). These terms are mainly replacing the classification in economic and extra-economic location factors. Soft and hard location factors are complementary and cover the whole spectrum of relevant dimensions in location decisions. Many scientists argue that it is often extremely difficult to separate them (Gabrow, 2005).

Some theorists' approaches (Thießen, 2005) describe "hard" location factors as the factors which can be measured objectively and soft location factors as the ones which cannot. The obtained numbers can easily flow into economic analyses and can be processed in various decision-making models. According to this delimitation, soft location factors are those ones which can be expressed in numbers only following a subjective evaluation. And still, the number of schools in an area, or the "cultural supply" as in the number of theatres, operas, cinemas, etc. can be easily determined.

Grabow is one of the main theorists using the classification hard-soft, and underlines the existence of two different categories of soft location factors (Grabow et. 
al, 1995). He discerns between enterprise-related location factors and personnel related ones. The most important hard and soft location factors are represented in the flowchart below.

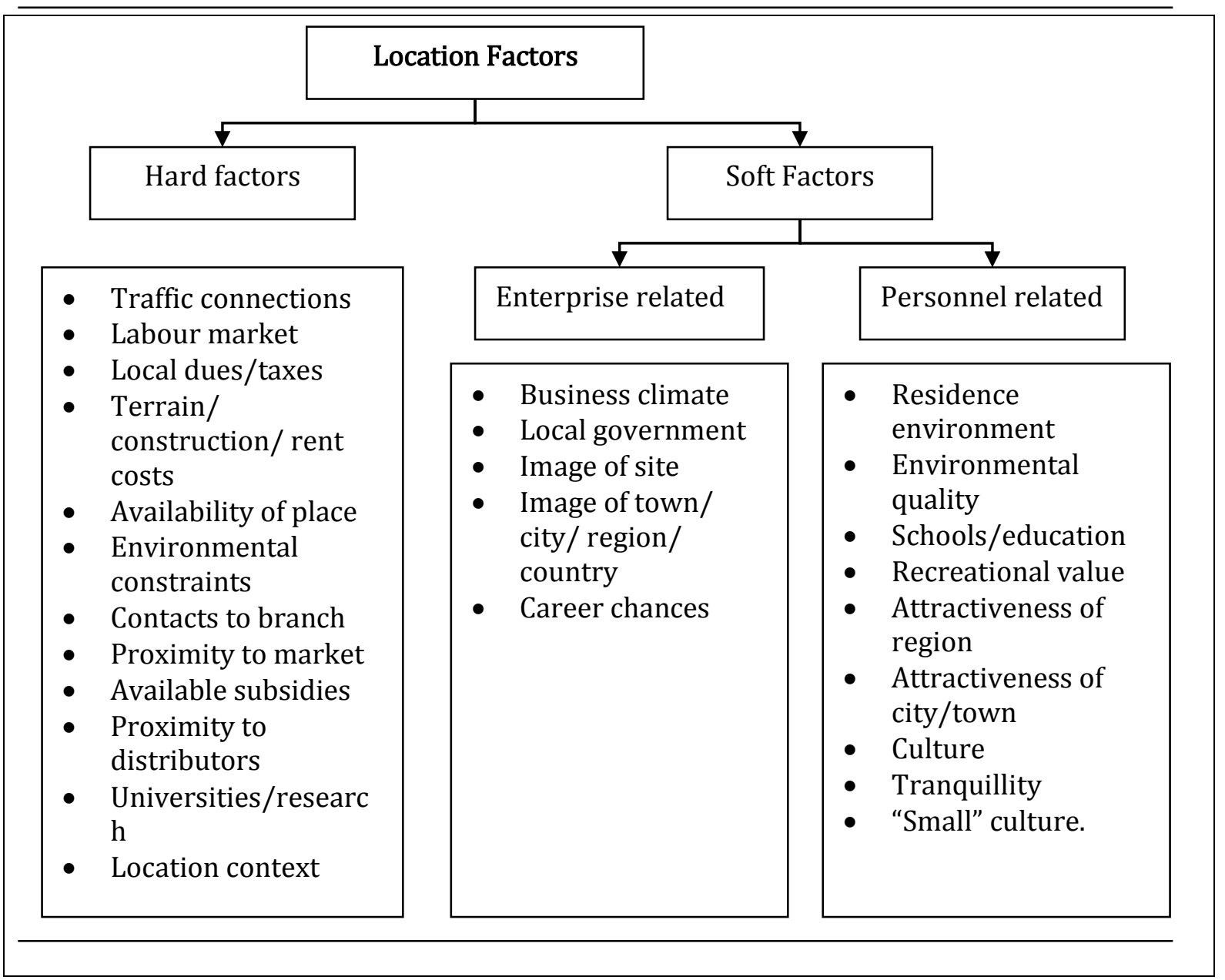

Figure 3. Classification of location factors after Grabow

Source: Kinkel, 2004, p. 43.

Grabow describes the relation between hard and soft factors as a continuum, expressed by the criteria "Possibility of measurement and relevance of subjective appreciation" and "Relevance for the undertaking's activity". Some soft location factors have a great direct effect on the undertakings' activity, they are just not objectively measurable: local government, image of location, population's mentality, social climate, recreational value. On the other hand, there are easily measurable soft location factors, e.g. the number of schools in the area, but these are just indirectly relevant for the undertakings' activity. These factors are usually of great relevance for the employees (and also for the decision makers).

When thinking in the context of the contemporary society based on services and information, soft location factors gain a completely new degree of importance. Firstly, it makes sense to go back to the theory of agglomeration, which underlines the raise of productivity in areas where many related and supportive industry operate at the same time. The reduction of production or distribution costs plays a secondary 
role in this matter. The practice shows that advantages like mutual learning and technology spill overs are the main motives in productivity raise. The "milieu concept" also finds empirical support. The agglomeration in "inspiring" areas leads to the creation of innovation and growth enhancing climates. A frequently used example for the upper affirmation is the development of the Silicon Valley.

The "tertiarisation" of the market, the modification of production conditions and the permanent change of technology lead to a change of values in the society, which consequently leads to the attribution of a greater importance to soft location factors. Authors preoccupied with the tertiary sector, like Albert Tóth (2016), stress the importance of factors such as safety and image of an investment location for the tourism sector, these considerations can be however generalised to other sectors, as well.

The competition of regions of today and tomorrow has less connection to cost leadership than ever. In order to be competitive, a region has to demonstrate its capability to adjust, or, how Läpple (2001) expresses it, to "tackle the new basis technologies and advance structural change by linking technological and organisational innovations".

Marketing intelligence studies show that organizations should understand the importance of continuously monitoring and adapting to their environment in order to increase their businesses' competitive advantage (Ladipo et al., 2017), the evergrowing ubiquity of hard location factors (especially of the traffic infrastructure) led to the fact that soft location factors won in terms of importance. In the circumstance of equivalent infrastructural conditions, the main difference between locations is made by soft location factors. The next chapter will show that the Member States of the EU, which are characterised by a high grade of ubiquity on these matters, should stress the development of their available soft factors more, in order to maintain and attract capital and labour.

\section{Empirical evidence: soft locational factors and FDI stocks}

In order to address the question of capital migration I chose to examine the foreign direct investment inward stocks of EU-Member States. My choice is rather contextual, since it is impossible for a single researcher to prevail statistically representative samples of operational data from enterprises who performed locational choices directed to several countries. FDI Stocks measure the total level of direct investment in a country at a given point in time, and data regarding stocks is largely available over both time and countries. I chose to analyse the Member States of the European Union, since these are undergoing a complex process of industrial, political, legal, economic, social and cultural integration and are also characterised by geographical closeness.

According to the United Nations Conference on Trade and Development, the source of the data analysed for associate and subsidiary enterprises, the FDI stocks measure the total value of the share of the foreign investors' capital and reserves (including retained profits) attributable to the parent enterprise, plus the net indebtedness of affiliates to the parent enterprise (United Nations, 2017).

In order to address the question of soft location factors, I chose to take a closer look at the World Bank's project "Doing Business". This initiative launched 2002 assesses business regulations across 190 economies worldwide (The World Bank 
Group, 2017). It thoroughly mirrors the business regulatory climate in each country as well as its evolution.

As a reflection of personnel-related soft locational factors I chose to analyse the findings of the World Happiness Report, a project initiated 2002 in support of the UN High Level Meeting on happiness and well-being (Helliwell et al., 2017).

\section{Ease of doing business}

Since 2002, the World Bank initiated the "Doing Business" project, gathering and analysing comprehensive quantitative data in order to compare business regulation environments across economies and over time. The primordial aim of the project is to encourage economies to compete towards more efficient regulation by offering measurable benchmarks for reform (The World Bank Group, 2017). The topics covered by this project are:

- Starting a Business (procedures officially required, or commonly done in practice, for an entrepreneur to start up and formally operate an industrial or commercial business, as well as the time and cost to complete these procedures and the paid-in minimum capital requirement).

- Dealing with Construction Permits (procedures required for a business in the construction industry to build a warehouse along with the time and cost to complete each procedure).

- Getting Electricity (procedures required for a business to obtain a permanent electricity connection and supply for a standardised warehouse)

- Registering Property (full sequence of procedures, incl. time and cost, necessary for a business -the buyer- to purchase a property from another business -the seller- and to transfer the property title to the buyer's name so that the buyer can use the property for expanding business, as collateral in taking new loans or, if necessary, sell the property to another business)

- Getting Credit (topic explores two sets of issues-credit information registries and the effectiveness of collateral and bankruptcy laws in facilitating lending)

- Protecting Minority Investors (strength of minority shareholder protections against misuse of corporate assets by directors for their personal gain)

- Paying Taxes (addresses the taxes and mandatory contributions that a medium-size company must pay or withhold in a given year, as well as measures of administrative burden in paying taxes)

- Trading across Borders (time and cost associated with the logistical process of exporting and importing goods)

- Enforcing Contracts (efficiency of contract enforcement by following the evolution of a sale of goods dispute and tracking the time, cost, and number of procedures involved from the moment the plaintiff files the lawsuit until actual payment)

- Resolving Insolvency (time, cost and outcome of insolvency proceedings involving domestic entities as well as the strength of the legal framework applicable to judicial liquidation and reorganisation proceedings).

Figure 4 shows the Overall distance to frontier for the EU Member States as calculated by the World Bank's Ease of Doing Business Project with 100 points for a 
utopic country which would perform best worldwide in all the above described categories.

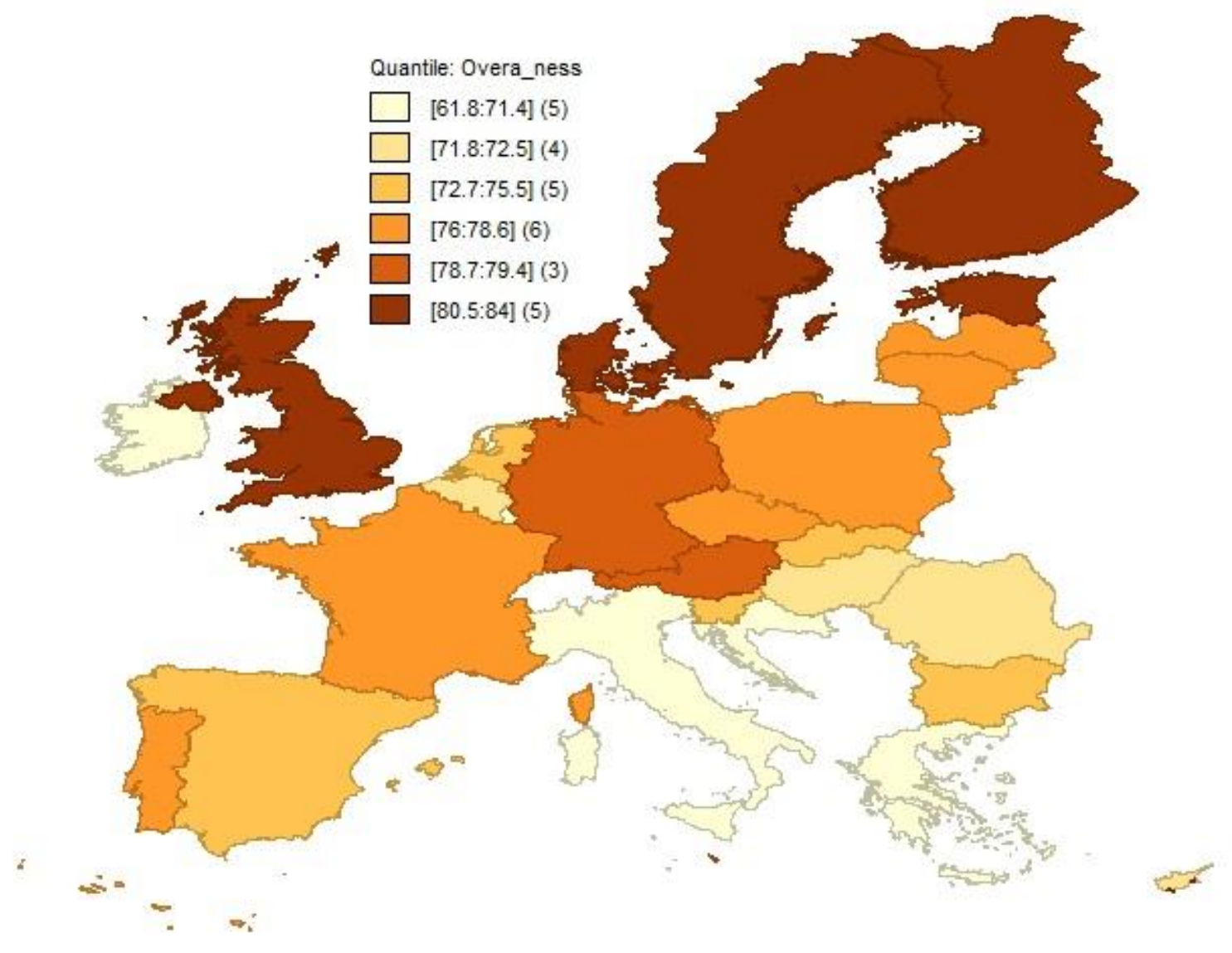

Figure 4. Overall distance to frontier for the EU Member States

Source: Author's contribution based on data available on www.doingbusiness.com for the year 2016.

\section{World Happiness Report}

The happiness score or subjective well-being is based on a survey released by the Gallup World Poll Dec 23, 2016 (Helliwell et al., 2017). The score indicates a national average response to the question of life evaluation: "Please imagine a ladder, with steps numbered from 0 at the bottom to 10 at the top. The top of the ladder represents the best possible life for you and the bottom of the ladder represents the worst possible life for you. On which step of the ladder would you say you personally feel you stand at this time?". The score ranges within the European Union from 4,83 in Bulgaria to 7,65 in Finland, as shown in Figure 5. 


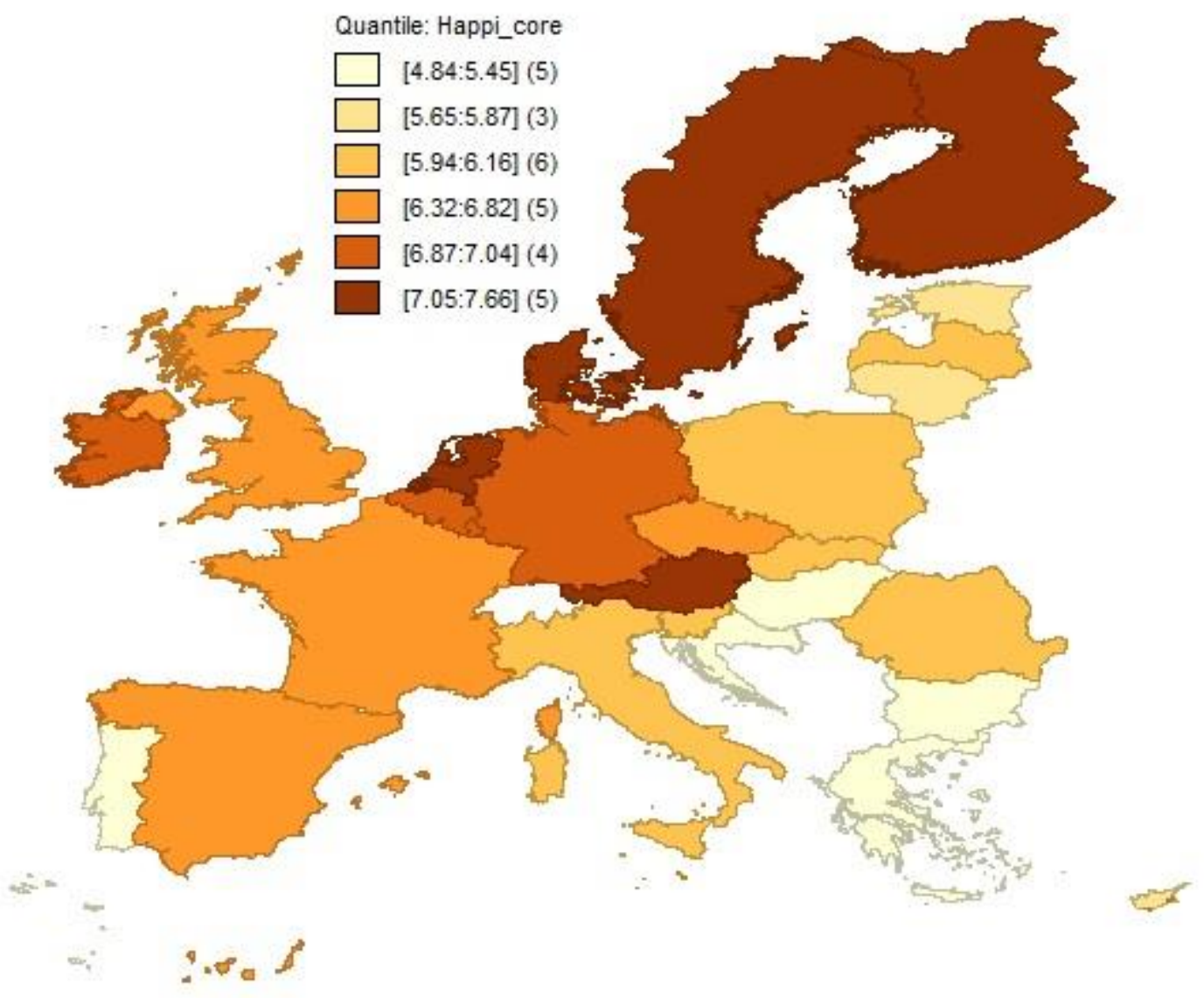

Figure 5. The Happiness score for the EU Member States

Source: Author's contribution based on data provided by Helliwell et al., 2017 for the year 2016.

\section{Methodology for the empirical analysis}

Meaning to show the connections between the chosen indicators in the case of 28 European Member States I decided to use the Pearson Coefficient. The analysed indicators are: the FDI inward stocks / capita, the Overall distance to frontier as calculated by the World Bank's Ease of Doing Business Project as well as the individual distances to the frontier of the project's sub-indicators and the Happiness score as calculated by the World Happiness Report.

The research included the analysis of the most recent available data for the 28 European Member States, namely: Belgium, Bulgaria, the Czech Republic, Denmark, Germany, Estonia, Ireland, Greece, Spain, France, Croatia, Italy, Cyprus, Latvia, Lithuania, Luxemburg, Hungary, Malta, Netherlands, Austria, Poland, Portugal, Romania, Slovenia, Slovakia, Finland, Sweden and the United Kingdom. The analysis was performed for all 28 countries, as well as for two separate country groups: the "old" Member States and the "new" ones (which adhered starting in 2004). Since Cyprus, Luxemburg, Ireland and Malta show significant deviations in FDI/capita terms, I decided to exclude them from the further analysis. Figure 6 shows the 
FDI/capita for the Member States. The four mentioned outliners are marked with deep red.

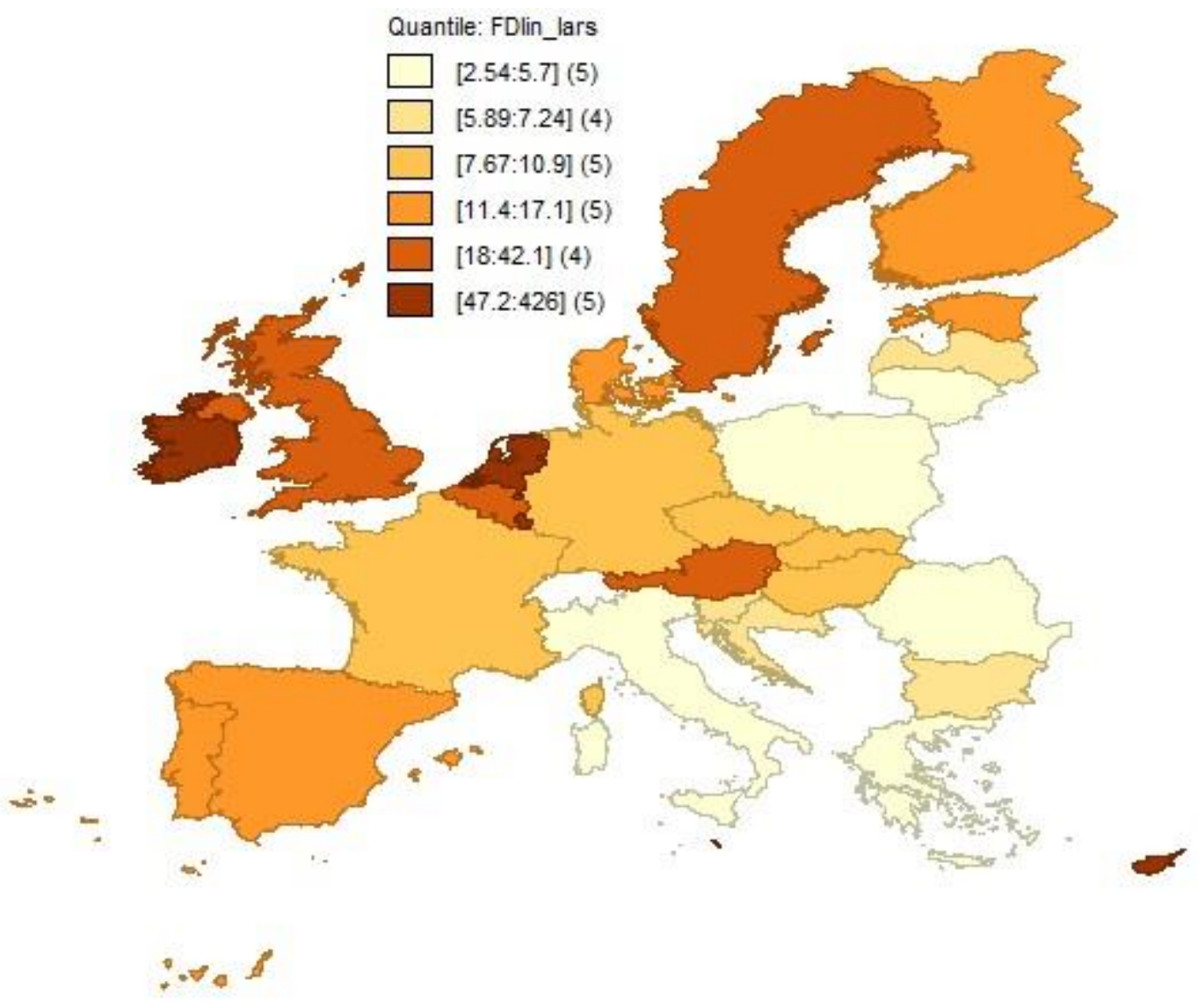

Figure 6. GDP inward stock per Capita within the 28 EU-Member States

Source: Author's contribution based on data provided by the UNCTED and Eurostat for the year 2016.

To see what type of correlations exists between the chosen indicators I used the Pearson Coefficient based on the covariance calculation formula for two variables:

\section{$(\mathrm{E}[(\mathrm{X}-\mathrm{E}(\mathrm{X}))(\mathrm{Y}-\mathrm{E}(\mathrm{Y}))]) / \sigma \mathrm{X} \sigma \mathrm{Y}$}

where $\mathrm{E}(\mathrm{X})$ and $\mathrm{E}(\mathrm{Y})$ are the averages of the $\mathrm{X}, \mathrm{Y}$ variables, while $\sigma \mathrm{X}, \sigma \mathrm{Y}$ are the standard deviations of the $\mathrm{X}, \mathrm{Y}$ variables. The subsequent table shows the analysis' findings.

Table 1. Correlation indicators for the FDI inward stocks/capita (Pearson's r coefficients)

\begin{tabular}{|c|c|c|c|}
\hline & EU28-4 & Old MS & New MS \\
\hline Ease of doing business - Overall DTF & $\mathbf{0 , 2 2}$ & $\mathbf{0 , 0 9}$ & $\mathbf{0 , 4 8}$ \\
\hline - Starting a Business - DTF & 0,44 & 0,47 & 0,26 \\
\hline - Dealing with Construction Permits - & 0,24 & 0,02 & 0,35 \\
\hline
\end{tabular}

Vol. 12, No. 4, Winter, pp. 633-651, ISSN 1842-0206 | Management \& Marketing. Challenges for the Knowledge Society 


\begin{tabular}{|c|c|c|c|}
\hline - Getting Electricity - DTF & 0,17 & $\underline{-0,18}$ & 0,51 \\
\hline$-\quad$ Registering Property - DTF & $\underline{-0,05}$ & 0,08 & 0,41 \\
\hline - Getting Credit - DTF & $\underline{-0,39}$ & $\underline{-0,31}$ & 0,01 \\
\hline$-\quad$ Protecting Minority Investors - DTF & 0,02 & $\underline{-0,09}$ & $\underline{-0,39}$ \\
\hline$-\quad$ Paying Taxes - DTF & 0,33 & 0,31 & 0,32 \\
\hline - Trading across Borders - DTF & 0,13 & 0,33 & 0,18 \\
\hline - Enforcing Contracts - DTF & $\underline{-0,02}$ & 0,02 & $\underline{-0,03}$ \\
\hline - Resolving Insolvency - DTF & 0,50 & 0,34 & 0,27 \\
\hline Happiness score & $\mathbf{0 , 6 6}$ & $\mathbf{0 , 6 0}$ & $\mathbf{0 , 1 3}$ \\
\hline
\end{tabular}

Source: Own research based on data provided by UNCTED, Eurostat, World Bank and the Sustainable Development Solutions Network.

When analysing the correlation between the Ease of Doing Business indicators and the FDI inward stock/capita, I found a strong correlation, with a positive Pearson coefficient of 0,48 within the New Member States (Bulgaria, Croatia, Czech Republic, Estonia, Hungary, Latvia, Lithuania, Poland, Romania, Slovakia and Slovenia). Since the accumulated FDI stocks for these countries start 1990 with " 0 ", the connection between the World Bank's evaluation of the overall business regulatory climate in the countries and their performance in attracting foreign capital is, as pointed out by the calculus, unquestionable. The ease of getting electricity $(0,51)$ next to registering property $(0,41)$ and dealing with contracts $(0,35)$ are the secondary factors with the highest correlations scores with the FDI stocks within these countries. These are factors where many of the Eastern European Member States, still don't perform very well. When taking a closer look at the two indicators, 2018 still only four out of the eleven countries occupied positions in the top 50, four countries occupied positions between 51 and 100 and three countries between 101 and 150 while on the overall Ease of doing business ranking ten out of eleven countries occupied positions in the top 50 and Croatia took the 51st position.

On EU-level, on the other hand, the overall ease of doing business indicator shows only a slight correlation $(0,22)$ with the FDI stocks, while the secondary factors 'Ease of resolving insolvency' and 'Ease of starting a business' are stronger correlated to FDI stocks.

The most significant correlation found was, however, between the FDI stock/capita and the Happiness score on EU-level, with a positive Pearson coefficient of 0,66 . The high correlation of factors $(0,60)$ also applies for the countries which became part of the EU before 2014, whereas there is no obvious correlation between these two factors with regard to the new Member States when analysed separately.

The analyse also resulted in two moderate negative correlations, with a Pearson Coefficient of $-0,39$ :

- one on EU level, between FDI stocks and the ease of getting credit. According to this finding, countries where getting credit is more complicated, are more attractive for FDI. 
- one within the new Member States, between FDI stocks and the strength of minority shareholder protection. This finding could suggest that new Member States might have overthrown the balance between local and external shareholders in their intention to attract external capital.

\section{Conclusions}

The number of disrupters from the theoretical framework by actual cases caused the contemporary approaches of the topic of locational factors to a change of view. Nowadays, the parameters which flow into the location decision making process are more and more diverse from case to case, which leads to formally ignored factors to be taken into account.

All the spatial decisions are conditioned by the dynamics of the outside world in which the enterprise must produce, sell and compete. The ever-growing ubiquity of hard location factors led to the fact that soft location factors generally won in terms of importance. In the circumstance of equivalent infrastructural conditions, the main difference between locations is made by soft location factors.

Eastern Europe is characterised by a high grade of ubiquity of hard factors and the countries' steps towards integration led me to the conclusion that they should be more concerned with the development of their soft factors.

In order to be successful in system competition, it is not enough for them to improve their economic factors, but it will have to deal with their extra economic ones, which influence their economic reality, as well. Public administration should not forget the fact that "the labour market" is created by settlements, which lead to entrepreneurial activities in an area and that labour force is attracted to a region by the quality of life, not by the demand of labour force exercised by existing enterprises.

At the same time the countries should be more concerned with their image. A more favourable country-image can be achieved through branding. In order to be able to realise "branding", they need to establish some positive brands, besides their common well-known dark, communist past.

Finally, the problem of soft locational factors should be addressed at local administrational levels - regions and communities - in order to be attractive for labour and capital as well, ability strongly connected to contentedness and happiness. Governments have to adapt their institutional design and develop long term policies which position them well within systems competition. The effects of systems competition are unfortunately not evident enough. Often the migration responses are so slow that a long period of time can elapse before a country is forced to react to another country's policy move.

Understanding the functioning of systems competition is of great importance for Eastern European countries because they entered a historical phase where the rules under which their companies interact are changing rapidly, and the results are not of immediate nature. The leaders of every country must now consider what influence their strategies can exercise on the cross-border transfer of economic activities. As evidenced by the data analysis performed, FDI stocks are strongly correlated with the business regulatory climate within the EU Member States, especially in Eastern Europe. The strong correlation to the happiness scale lets me conclude that states should also be equally concerned about FDI stocks and the state 
of mind of their inhabitants, since happiness and FDI stocks are strongly correlated. The limitations of this study are first of all of geographical and temporary nature. Further on, other factors should be taken into account. As a future research agenda, these countries' dynamics should be modelled over a longer time span in order to identify causality relations and to be able to develop complex scenarios. Including other factors into the analysis, as well and extending the analysis to other geographical regions could lead to more complex results. Another limitation of this paper is the lack of empirical data from decision makers from the business environment. Further results should be tested by an extensive analysis of their preferences and choices.

\section{References}

Albert Tóth, A. (2016), "The Impact of the Hotel Industry on the Competitiveness of Tourism Destinations in Hungary", Journal of Competitiveness, Vol. 8, Issue 4, pp. 85-104.

Auer, P., Besse, G. and Méda, D. (2005), "Offshoring and the Internationalisation of Employment. A challenge for a fair globalisation?", Proceedings of the France/ILO symposium ILO Agency, available at: www.ilo.org/wcmsp5/groups/ public/---dgreports/---dcomm/--publ/documents/publication/wcms_ 071687.pdf (accessed October 15,2017).

Bundesarbeitsgemeinschaft der Mittel- und Gro-betriebe des Einzelhandels e.V. (BAG) (1979), "Unternehmensplanung im Einzelhandel - Wege zukunftsorientierter Unternehmensführung", Köln.

Behrens, K.C. (1961), "Allgemeine Standortsbestimmungslehre", Westdeutscher Verlag, Köln.

Bienert, M.L. (1996), "Standortmanagement Neue betriebswirtschaftliche Forschung", Gabler, Wiesbaden.

Boddy, M.J. (1987), "Structured approaches to industrial location", in: Lever, W.F. (Ed.), Industrial change in the United Kingdom, Longman, London.

Gabrow, B. (2005), "Weiche Standortfaktoren in Theorie und Empire - Ein Überblick", In Thießen, F. (Ed.), Weiche Standortfaktoren: Erfolgsfaktoren regionaler Wirtschaftsentwicklung; interdisziplinäre Beiträge zur regionalen Wirtschaftsforschung, Duncker \& Humblot.

Grabow, B., Henckel, D. and Hollbach-Grömig, B. (1995), Weiche Standortfaktoren, Kohlhammer, Stuttgart, Berlin, Köln.

Helliwell, J., Layard, R. and Sachs, J. (2017), "World Happiness Report 2017", New York: Sustainable Development Solutions Network, available at: worldhappiness.report/wp-content/uploads/sites/2/2017/03/HR17.pdf (accessed October 13, 2017).

Hansmann, K.-W. (1974), Entscheidungsmodelle zur Standortplanung der Industrieunternehmen, Gabler, Wiesbaden.

Healey, M. J. and Ilbery, B. W. (1992), Location and change: perspectives on economic geography, Oxford University Press, Oxford.

Johnson, D.B. (1978), "The West Edmonton Mall - from super-regional to megaregional shopping centre", International Journal of Retailing, Vol. 2, No. 2, pp. 53-69. 
Kinkel, S. (2004), Die Strategie im Fokus: Erfolgskritische Standortfaktoren für verschiedene Internationalisierungsstrategien in Erfolgsfaktor Standortplanung: in- und ausländische Standorte richtig bewerten, Springer, Berlin.

Laulajainen, R. and Stanford, H. A. (1995), Corporate geography: business location principles and cases, Kluwer Academic Publications, Dordrecht.

Ladipo P.K. A., Awoniyi M.A. and Arebi I.T. (2017), "The influence of marketing intelligence on business competitive advantage (a study of Diamond Bank Plc)", Journal of Competitiveness, Vol. 9, No. 1, pp. 51-71.

Läpple, D. (2001), "City and region in an age of globalisation and digitalisation", German Journal of Urban Studies, Vol. 40, No. 2.

Massey, D. (1981), "The geography of industrial change", in Potter, D. (Ed.), Society and the social science, Routledge and Kegan Paul in association with the Open University Press, London.

Massey, D. (1984), Spatial divisions of labour, Macmillan, London.

Miron, D., Dima, A. M. and Vasilache, S. (2009), "Indexes of Regional Economic Growth in Post-Accession Romania", Romanian Journal of Economic Forecasting, Vol. 11, No. 3.

Reichhardt, R. M (1991), Aufgabe und Vorgehensweise der Standortanalyse von Filialenbetrieben, Gesellschaft für Konsumforschung, Nürnberg.

Sinn, H. W. (2003), The new system competition, Basil Blackwell, Oxford.

The World Bank Group (2017), "Doing Business". Benchmarking Business Regulations www.doingbusiness.org, (accessed October 14, 2017).

Thießen, F. (2005), "Zum Geleit: Weiche Standortfaktoren - Die fünf Sichtweisen”, In: Thießen, F. (Ed), Standortfaktoren: Erfolgsfaktoren regionaler Wirtschaftsentwicklung; interdisziplinäre Beiträge zur regionalen Wirtschaftsforschung, Duncker \& Humblot, Berlin.

UNCTD (2017), World Investment Report 2017. Investment and the digital economy, United Nations, Geneva.

Walmsley, D.J. and Leevis, G.J. (1984), Human geography: behavioural approaches, Longman, London. 